\title{
Taraxacum pseudomark/undii, a south-western European species, native in South Devon (v.c.3).
}

\author{
John J. Day ${ }^{1}$; A. John Richards ${ }^{2 *}$ \\ ${ }^{1}$ South Brent, Devon, UK; ${ }^{2}$ Hexham, Northumberland, UK \\ * Corresponding author: A. John Richards: hightreesgarden@btinternet.com
}

This pdf constitutes the Version of Record published on $26^{\text {th }}$ February 2020

\begin{abstract}
An enigmatic dandelion first collected in the UK in 2014 from a lanebank on Dartmoor (v.c.3) has been determined as Taraxacum pseudomarklundii (Soest), previously only known from north-west Spain and south-west France, an unusual biogeographic alliance in our Taraxacum-flora. It is triploid $(2 n=24)$. This taxon has now been confirmed from several locations in South Devon and one site in Ireland (Meath, v.c.H22).
\end{abstract}

Of the 150 or so Taraxacum agamospecies recorded from the British Isles that occur elsewhere in Europe, most have North Atlantic, Scandinavian, or South Baltic to Germanic affinities, and only a very few ( $T$. drucei Dahlst., $T$. nietoi A.J. Richards) are otherwise found in south-west Europe. There is a preponderance of sexual Taraxaca at low altitudes south of Paris and if these forms are ever introduced to Britain and Ireland, they have never been detected here. In these southern sexual areas one cannot distinguish microspecies. However, it seems likely that in farwestern Iberia ('Green Spain') sexuality in dandelions is rare or absent. This needs further investigation, but a number of distinctive agamospecies have been named from this region. Many agamospecies are also known from higher altitudes in the Pyrenees, Alps and Massif Central.

On April $15^{\text {th }}, 2014$, JJD collected a dandelion from a steep Dartmoor lane-bank at $265 \mathrm{~m}$ (Yalland, near South Brent) and sent it to AJR. The salient features were of a rather delicate plant with strongly recurved leaf-lobes, which are very convex distally, the leaves bearing markedly acuminate terminal leaf-lobes. Any resemblance to familiar species classified in section Hamata H. Ollg., such as T. marklundii Palmgr. were dispelled by the narrow erect, blackish exterior bracts, orange-yellow ligules with purple teeth, blackish stigmas and torpedo-shaped achenes with a body $3.8 \mathrm{~mm}$ long. AJR first likened this plant to the type of the enigmatic T. hibernicum Hagl., which was later considered to represent a cultivated form of T. mark/undii Palmgr. (Richards \& Doogue, 2018). In a later note in 2017, AJR noted a resemblance to $T$. prionum Hgdk, Soest \& Zevenb., and tentatively suggested a workname 'T. subprionum'. However, he suggested that JJD should cultivate material, which he did over the next two years, making a full record of the various phenotypes produced during different seasons.

The breakthrough came when Jelle Hofstra, who has studied the Taraxaca of south-west France, identified photographs of dried and living material as $T$. 
pseudomark/undii Soest (1954). This early publication of Soest described a few species from Santander, north-west Spain collected for him by E. Leroy. Soest noted the superficial resemblance to $T$. mark/undii, but distinguished his new species by the absence of pollen, the clear colour of the flowers, and the yellowish colour of the leaves which are partially spotted. The description and figure also clearly show dark, narrow, erect exterior bracts. Since then, T. pseudomark/undii has been found at several sites in south-west France and Hofstra sent pictures of material from Perville and Bourg-de-Visa (both Tarn-et-Garonne) which are an excellent match for Devon plants. Hofstra stated that this species varies considerably in the production of leaf spots, and noted that some of the Devon material is indeed spotted (missed by JJD and AJR!). However, he also acknowledged that Devon plants possess pollen, unlike T. pseudomark/undii s.s.. Flora Gallica recognises a complex of species related to T.pseudomark/undii, several as yet unnamed. T. rigescens Sonck from the western French Pyrenees is similar to T. pseudomark/undii and possesses pollen, but is not the same as Devon plants. Other unnamed forms have been recognised from Britanny and the Limousin. Hofstra's view is that Devon plants only differ from $T$. pseudomark/undii Soest. s.s. in the possession of pollen, and until the complex in France is studied more closely, our view is that this is the best name for our plants. While this account was being prepared, a typical specimen was identified amongst Irish material collected in Meath, $\mathrm{H} 22$ by Margaret Norton.

With respect to British and Irish Taraxaca, it is easier to identify the closest relatives of $T$. pseudomark/undii than to suggest a sectional affinity. The narrow, dark, erect bracts, clear dark yellow flowers and ligules with purple teeth, together with rather tenuous leaves with a slender petiole and the sporadic development of violet flecking on the upper leaf surface (Fig. 1) are all strongly reminiscent of $T$. ronae L.J. Margetts, a British Isles endemic which was described from Devon and Cornwall, but which is commoner in Ireland, where it is usually unspotted (v. immaculatum A.J. Richards ex Richards \& Doogue, 2018). The Cornish endemic $T$. cornubiense A.J. Richards also shares the unreliable leaf flecking and other features of $T$. pseudomark/undii, although the bracts are less erect. Yet another southwestern and Irish species, the reclusive $T$. drucei Dahlst. is also a relative. Consequently, it too may also have, as yet undetected, unspotted forms, which should be sought in its potential habitats. Like T. pseudomark/undii, T. drucei has disjunct stations in north-west Spain.

So far, this species-group has been classified in Taraxacum section Naevosa M.P. Christansen on account of the spotted leaves. However most members of that section are more robust and hairy, and have a North Atlantic affinity. Also many are tetraploid $(2 n=32)$. T. pseudomarklundii is triploid $(2 n=24)$ according to an unpublished count attached to a specimen grown from seed collected in the French Auvergne (unlocalised) by AJR in 1967 (OXF), which is a very good match for Devon material. Possibly these species are better thought of as rather typical members of section Celtica A.J. Richards which sometimes produce spots.

Unlike many other uncommon dandelions, it is of frequent occurrence within its known geographical range. To date, Taraxacum pseudomarklundii has been recorded from the following monads in South Devon (v.c.3); voucher material presently resides with JJD: SX4870, SX6545, SX6962, SX7159, SX7372, SX7679, SX7762, SX7862, SX8062, SX8266, and SX8486. This involves the following eight 
South Devon hectads: SX47, $64,66,75,76,77,86,88$. There is also a record from Kilmessen, N8857, Meath H22, Ireland. 11/03/2019, M. Norton.

About $70 \%$ of collections of $T$. pseudomarklundii come from steep, grassy, lane banks, the classic habitat for another rare Devon dandelion, T. subericinum Hagdk., Soest \& Zevenb. (Rich \& Richards 2011). All of the known sites are well-drained, ungrazed, mesotrophic, herbaceous or grassy and the majority lack shade.
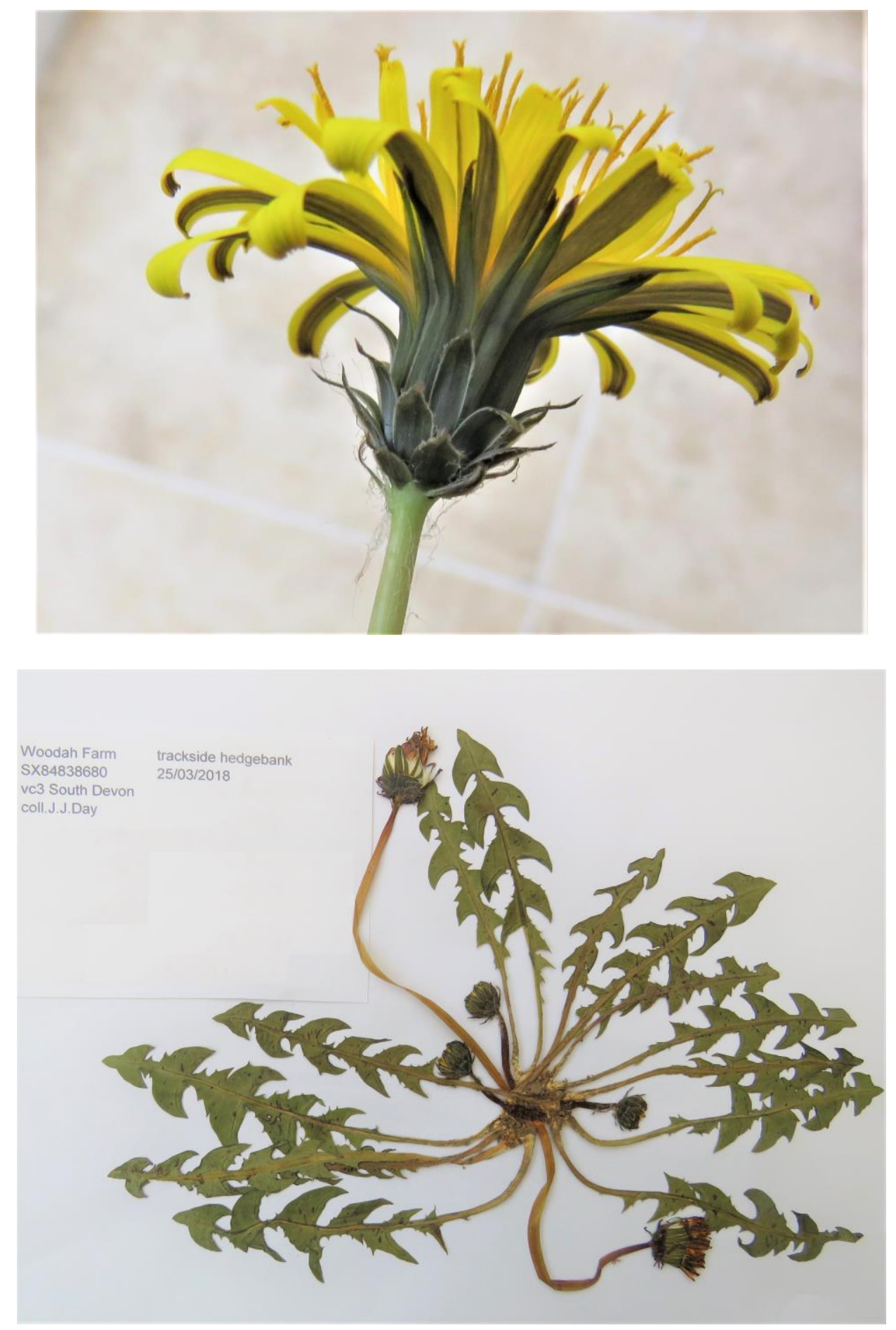

Figure 1. Taraxacum pseudomarklundii from South Devon (v.c.3) 
Occurrence of this preferred micro-habitat appears to be the main factor affecting its distribution within South Devon as it occurs across a wide range of geological formations (limestone, mudstone, sandstone and shale) and from within $1 \mathrm{~km}$ of the sea, at $40 \mathrm{~m}$ altitude, to lane sides on Dartmoor, at $305 \mathrm{~m}$. It has not been found either on the granites or unenclosed areas of Dartmoor.

Where conditions are favourable, Devon hedge banks often hold species rich assemblages of native dandelions. 'Such sites can be taraxacological paradises' (Dudman \& Richards, 1997). Peak flowering for native Taraxacum species on South Devon hedge banks is a short-lived phenomenon and tends to occur over the last two weeks of April but varies considerably with slope and aspect even over short distances. Amongst the native taxa, T. pseudomark/undii is noticeably early to flower (February onwards). For half of the collections it was the only dandelion in flower anywhere within the local vicinity. This tendency for early flowering aids the field detection and collection of specimens. Early flowering may also be linked to a lack of competitive ability in this small, low-growing and attractive species.

\section{References}

Dudman, A.A. \& Richards, A.J. 1997. Dandelions of Great Britain and Ireland. BSBI Handbook No. 9. London: Botanical Society of the British Isles.

Rich, T.C.G. \& Richards, A.J. 2011. Taraxacum subericinum new to the British Isles. BSBI News 117: 45.

Richards, A.J. \& Doogue, D. 2018. Notes on some Taraxacum (Asteraceae) from Ireland including description of four new Celtica species. New Journal of Botany 7: 136-148.

Soest, J.L. van 1954. Sur quelques Taraxaca de la province de Santander. Trabajos del Jardin Botanico Santiago de Compostela III: 3-7.

Copyright retained by author(s). Published by BSBI under the terms of the Creative Commons Attribution 4.0 International Public License.

ISSN: $2632-4970$

https://doi.org/10.33928/bib.2020.02.073 